\title{
Almira Yusupova* \\ POSITION OF LEADING CORPORATIONS: EMPIRICAL EVIDENCE FROM RUSSIAN ECONOMY
}

\begin{abstract}
The paper deals with the analysis of the role and ranking positions of leading corporations. Basic approach of industrial economics is used as the starting point of the analysis. Special coefficients of "sustainability" and "stability" of leadership, indicating companies' positions, are proposed to describe firms' market power. Empirical part is based on data provided by national rating agency Expert Ra for a long-term period from 2000 to 2011. Comparison of national and regional markets enabled us to find out that generally the positions of Russian leading corporations are stable and sustainable. Market power of leading companies is rather significant, therefore at the national level, competition could hardly be intensive. More competitive structures are developed at regional level. Regional markets demonstrated more rapid response to crisis. At the same time, expansion of national and transnational corporations has great influence on regional markets' structures.
\end{abstract}

Keywords: leading corporations, market power, stability and sustainability of leadership.

\section{INTRODUCTION}

The emergence of real industrial markets in Russian economy have taken place for the last 20 years. The level of economic activity of large enterprises and the dominance (market power) of one or several firms are among most important market characteristics. This dominance plays a crucial role in many local production systems. Large corporations play the key role in economic development within many Russian local production systems, since they provide the major portion of jobs, maintain all facilities, and determine general situation. One cannot overestimate the contribution of large corporations at national and regional levels. Current structure of most markets in Russia and market structure in general is related to the activities of few large companies. Leading position gives market power to the company. It is important to determine whether there are such market leaders and, if so, how stable their leading position is. Market leadership is considered an important determinant of market structure. This paper deals with the analysis of the nature of market leadership in the Russian economy.

* Novosibirsk State University, Institute of Economics and Industrial Engineering of the Siberian Branch of Russian Academy of Sciences. 
It also proposes an approach to the analysis of company's leading position. Within this approach we analyze "sustainability" and "stability" of the leading position and thus the market power in the industrial market.

\section{GENERAL CHARACTERISTICS OF MARKET LEADERSHIP}

Large corporations play an important role in the economies of most countries and regions. They make significant contribution to the main economic indicators, occupy key market positions, and their performance has got great impact on the development of national and local economies. These companies usually have huge investment potential. Historical background and contemporary integration processes have created very specific conditions in Russia. Under such environment, the role of leading companies is especially important. Our estimations show that in 2007, the total turnover of 20 largest companies was equal to $37 \%$ of the GDP; similar indicator for 10 companies was equal to $28 \%$. In 2010, after the crisis, these figures increased and were about $38 \%$ and $30 \%$ accordingly. Figure 1 shows the share of 1, 3, 5, 20 and 50 largest companies in the total turnover of 400 national leaders - conditional concentration ratios $\mathrm{CR}_{1}$, $\mathrm{CR}_{3}, \mathrm{CR}_{5}, \mathrm{CR}_{20}, \mathrm{CR}_{50}$.

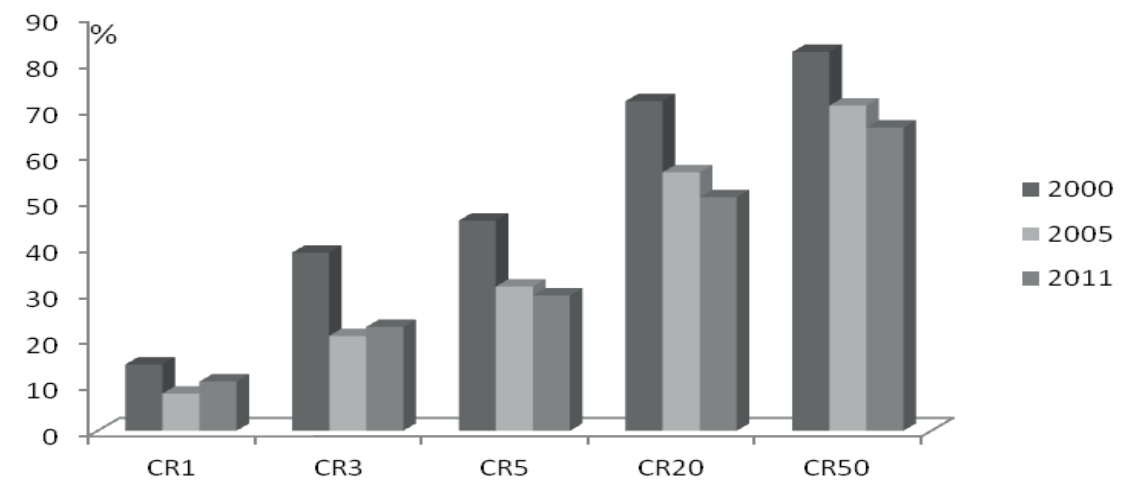

Figure 1. Share of the top 1 (CR1), 3 (CR3), 5 (CR5), 20 (CR20) and 50 (CR50) companies in the group of 400 Russian corporations leading in turnover, \% (estimated based on the data provided by ExpertRa agency)

Source: author's calculations.

Results show that large companies are very different. In 2011, the first 20 companies (of 400 ) generated almost $50 \%$ of all turnover. It is possible to note that most markets are characterized by the existence of definite leaders. Is should be mentioned that shares of 5,20 and 50 leaders decreased during 
2000-2011. $\mathrm{CR}_{1}$ and $\mathrm{CR}_{3}$ coefficients increased, but their value is influenced by many non-market reasons, which include strong state support of selected companies.

The main aim of this research is to develop and apply a framework for the analysis of the nature of market leadership within industrial markets. Research deals with the determination of leadership characteristics in Russian markets. If well recognized, corporations manage to save their strong market positions during long term period it is possible to define already developed and shaped market structures, which help us to predict companies' behavioural models.

A broad descriptive model of industrial markets development was conceived by Edward Mason and developed by Joe Bain. It is well known as The Structure - Conduct - Performance Paradigm ${ }^{1}$. Any industrial market structure is described with several basic structural indicators. Level of economic activity of large enterprises and level of dominance (market power) of one or several firms are among such indicators. Concentration is one of the main characteristics of market structure, it reflects the number of firms in the market and shows how much they differ from each other. Concentration is related to the level of competition and the market power of selected firms. It is known from the economic theory that the level of concentration should be rather low in competitive markets. At the same time, competition led to companies' consolidation and increased concentration ${ }^{2}$.

The main part of economic activities concentrates in a limited number of large companies. N. Collins and L. Preston analyzed changes in the lists of American leading corporations since the beginning of the $20^{\text {th }}$ century ${ }^{3}$. They found out that the list was not stable. Changes were explained by many factors, but the most important role was played by demand. The list of U.S. market leaders became more stable in the middle of the $20^{\text {th }}$ century, due to the following reasons:

- positions of large firms became stronger,

- a rate of demand changes decreased,

- management turned to be more professional,

- economic activities got diversified character.

Companies (even large corporations) usually are limited in their capability to outrun their competitors based only on their own strategic resources and competencies. Leading corporations play an important role in the creation of partnership relations. Nature and character of relational resources, the role of partnership cooperation as a tool of relational resources' potential increase and

\footnotetext{
${ }^{1}$ Scherer M., Ross D. (1991), Industrial Market Structure and Economic Performance, Houghton Miffin Company, Boston, p. 714.

${ }^{2}$ Perloff J.M., Carlton D. (2004), Modern Industrial Organization, Addison Wesley, p. 392.

${ }^{3}$ Collins N.R., Preston L.E. (1961), The Size Structure of the Largest industrial Firms, "American Economic Review", vol. 51, p. 986-1011.
} 
other similar issues are discussed in a number of research papers ${ }^{4}$. These relations are especially important for companies which have high level of innovative activities ${ }^{5}$.

Leading companies and their market positions traditionally attract attention of many researchers ${ }^{6}$. A number of papers are devoted to their role and place in globalization process and to the situation in particular industries ${ }^{7}$. At the same time, rather few of them analyse leadership in the context of industrial market structure. Such attempt is presented below.

Current structure of many markets in Russia, and market structure in general, is related to the activities of few large companies. Leading position gives market power to a company. It is important to determine, whether there are such market leaders and if so - how stable their leading position is.

An approach to the analysis of company's leading position is proposed in the paper. Within this approach we analyze "sustainability" and "stability" of the leading position and thus, market power in the industrial market. In any market we can identify a group of leading firms based on different criteria. It is possible to set up a group of top $(10,20$, etc.) firms - leaders according to the level of sales, profit, cost of assets, value added etc. Several groups of leaders can be defined according to different criteria in each market. All these groups may include either the same or different firms. In most cases some intersections take place. According to our definition, "sustainability" of the leading position of a company means the company is one of the leaders more than once, i.e. is in more than one group. If the leading position is sustainable, it is achieved based on various criteria and the groups intertwine. If the leadership is unsustainable, groups of leaders differ a lot.

"Stability" of firm's leading position in our approach means that it remains at the top for several (more than one) years (long-term leadership).

Summing up the above quoted definitions, we could say that the leading position of a firm is sustainable and stable if it is based on various criteria and maintained over the long term. If there are such firms in a certain market, leadership at this market is sustainable (or stable) and it is possible to make forecasts

${ }^{4}$ Cheung M.S., Myers M., Mentzer J.T. (2010), Does Relationship Learning Lead to Relationship Value?: A Cross-national Supply Chain Investigation, "Journal of Operations Management", no. 28(6), p. 472-487.

${ }^{5}$ Ziólkowska M. (2014), Relational Resources Management as Source of Company's Innovativeness and Competitive Advantage, "Journal of Economics, Business and Management", vol. 2, no. 3, p. 202-208.

${ }^{6}$ Toporowski J. (2010), The Transnational Company after Globalization, "Futures", vol. 42, issue 9, p. 920-925.

${ }^{7}$ Yang C., Shy J. (2009), Cross-national and Cross-industrial Comparison of two Strategy Approaches for Global Industrial Evolution, "Technological Forecasting and Social Change", vol. 76, issue 1, p. 2-25. 
on the further development and main tendencies in this market. Such a market structure can be considered mature; it can be adjusted and influenced by leading corporations.

We propose a special indicator - sustainability (stability) coefficient (CS).

$$
C S=1-\frac{N_{\text {fact }}-N_{\min }}{N_{\max }-N_{\min }}
$$

where:

$N_{\text {fact }}$ - the real number of leading firms represented in all groups,

$N_{\min }$ - minimum possible number of leading firms represented in all groups,

$N_{\max }^{\min }$ - maximum possible number of leading firms represented in all groups.

The value of the coefficient varies from 0 to 1 . If it is equal to 0 , it means that leadership is unsustainable (unstable). If it is equal to 1, it means that leadership is absolutely sustainable (or stable). It should be noted that the coefficient characterizes general market situation and it applies to the whole market.

It is important to note that suggested coefficients are relevant to the analysis of the whole market. The leading role and the position of each individual company is taken into account in the calculation, but indicators are used to describe the general market structure.

The main aim of the paper is to analyze the nature of market leadership in Russia at national and regional levels. Thus we studied the dynamics of the indicators over the long term and compared national and regional markets. Based on the assumption of classical industrial economics, we looked at the stability and sustainability of groups of Russian leading companies. Empirical basis was presented by annual rating Expert 400, provided by ExpertRa agency. We have chosen the following years: 1995, 2000, 2005, 2008, 2009, 2010, 2011. This time interval includes periods of economic stability as well as the years, in which it was absent.

For each year, we set up groups of companies with the highest turnover, gross profit and level of capitalization. Then, we compared companies included in these three groups. The assumption was that if a company is a market leader according to several criteria, its position is sustainable. The existence of such companies confirms that market structure is mature; market development tendencies can be forecasted based on the performance of leading companies. If groups of leading companies do not overlap, the leadership in the market is unsustainable and market structure is uncertain ${ }^{8}$.

\footnotetext{
${ }^{8}$ See Yusupova A. (2009), Structural characteristics of modern Russian industrial markets, "Region: Economics and Sociology", no. 4, p. 175-194.
} 


\section{LEADERSHIP OF RUSSIAN AND SIBERIAN CORPORATIONS}

For the purpose of our analysis we used two groups of companies consisting of 20 and 5 leading firms, respectively. The stability of leadership was estimated by comparing these two groups and their membership in different years. Leaders were determined using the turnover criterion. The analysis was conducted for the national economy and for the Siberian region. Results are presented in figures 2 and 3.

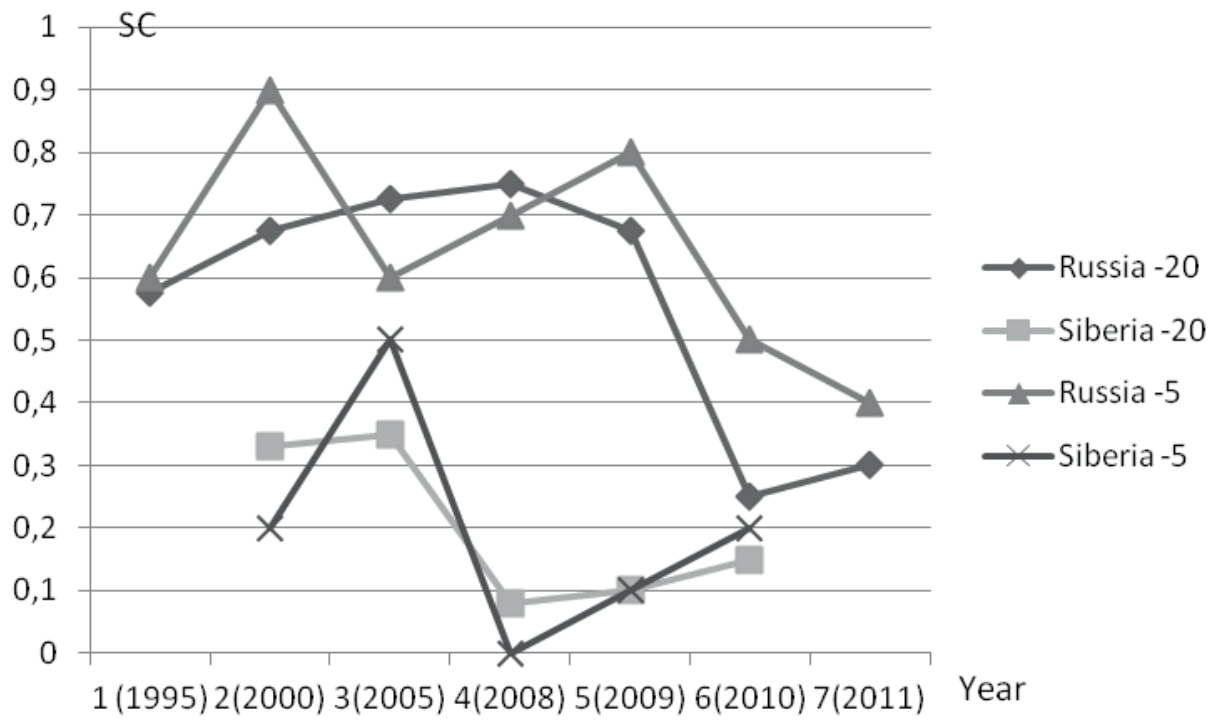

Figure 2. Sustainability coefficients (SC) for Russian and Siberian leaders

Source: author's calculations.

Results show that in general, the sustainability of leadership at the national level was rather high till 2008. It means that the same firms ranked at the top according to different criteria. That is indicative of the market structure, which was rather mature with potentially not very intensive competition, far from perfect. Large corporations enjoyed substantial market power. The above is true of both groups of leaders including 20 and 5 firms. Sustainability of 5 leaders was slightly lower than that of 20 , except the year 2000. In our opinion that can be explained by noneconomic factors.

In 2009, the coefficient of leadership sustainability decreased for 20 firms and increased for 5, but in 2010 all coefficients significantly decreased. Such dynamics can be explained by the reaction to general instability in the times of crisis and in its aftermath. Companies faced difficulties in maintaining top 
positions in all rankings. In 2011, economic recovery resulted in further increases of the coefficients?.

For Siberian companies the picture is quite different. Sustainability coefficients of leadership in general are lower than national ones. This is observed for both groups of 5 leaders and 20 leaders. As a result, the positions of regional leaders are weaker and more competitive structures are developed at regional level. Also the response to crisis could be observed sooner at regional level. Already in 2008 the SC for 20 leaders significantly decreased and the $\mathrm{SC}$ for 5 leaders was even equal to 0 . Increase in indicators was observed already in 2010, which also reflects quicker reaction to general changes than in national markets.

The dynamics of national and regional coefficients was different. There were years when they even demonstrated opposite trends. Difference between national and regional markets is more clear for 5 leaders. Based on the above, we can conclude that regional economy has got its specificities.

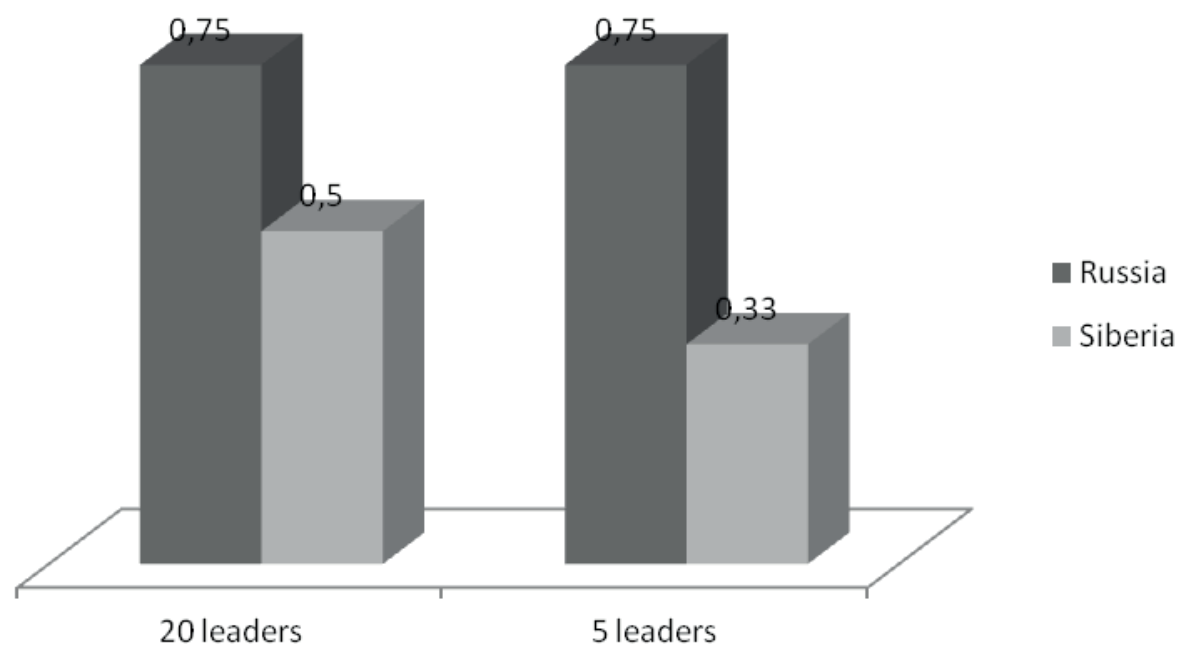

Figure 3. Stability coefficients for Russia and Siberia

Source: author's calculations.

Stability of leadership over the long term is reflected in figure 3 . These data are less relevant for the times of crisis. In general, stability indicators are rather high. We may expect that the indicator for Russia would be even higher without state interference (the case of state-owned Ukos company).

\footnotetext{
${ }^{9}$ It should be noted, that some corporations are actually affiliated with each other (for example Gasprom and Gaspromneft). Formally, they are separate entities, their results are registered separately. Therefore real sustainability of leadership should be higher than estimated.
} 
Stability of Siberian leaders was lower comparing with the national level. Tables 1 and 2 show some characteristics of leading corporations. As we can see, most of them operate in strategic sectors of the economy, such as oil and gas. Competition in these markets is not high. In 2005, 9 out of 20 leading companies operated in the oil and gas sector, while in $2011-8$ leaders belonged to it. In general, most of the leading corporations are connected with fuel and energy supplies. On top of that, the list of leaders includes well known national monopolies, such as Russian Railways and Sberbank.

Table 1

Industrial profile of 20 Russian leading corporations (number of firms in each industry)

\begin{tabular}{|l|l|}
\hline \multicolumn{1}{|c|}{$\mathbf{2 0 0 5}$} & \multicolumn{1}{c|}{$\mathbf{2 0 1 1}$} \\
\hline- Oil and gas -9 & - Oil and gas -8 \\
- Banks -1 & - Banks -2 \\
- Non ferrous metallurgy -1 & - Non ferrous metallurgy -2 \\
- Telecommunications and communications -3 & - Chemical and petrochemical industry -1 \\
- Electrical power engineering -1 & - Telecommunications and communications -2 \\
- Ferrous metallurgy -4 & - Electrical power engineering -2 \\
- Food industry -1 & - Ferrous metallurgy -2 \\
& - Precious metals and diamonds industry -1 \\
\hline
\end{tabular}

Source: author's calculations.

Industrial specificity is reflected in the levels of calculated indicators of stability and sustainability of leadership. The list of Siberian leaders includes companies, which belong to national giants. They pursue regional expansion, tending to widen their areas of influence.

Table 2

Industrial profile of 20 Siberian leading corporations (number of firms in each industry)

\begin{tabular}{|l|l|}
\hline \multicolumn{1}{|c|}{$\mathbf{2 0 0 5}$} & \multicolumn{1}{c|}{$\mathbf{2 0 1 0}$} \\
\hline- Oil and gas -2 & - Oil and gas -2 \\
- Non ferrous metallurgy -3 & - Non ferrous metallurgy -2 \\
- Telecommunications and communications, IT -1 & - Telecommunications and communications, IT -1 \\
- Electrical power engineering -3 & - Electrical power engineering -4 \\
- Ferrous metallurgy -3 & - Ferrous metallurgy -1 \\
- Transport -2 & - Transport and logistics -2 \\
- Coal and turf industry -6 & - Coal and turf industry -3 \\
& - Trade -2 \\
& - Banks -1 \\
& - Manufacturing -1 \\
& - Precious metals industry -1 \\
\hline
\end{tabular}

Source: author's calculations. 
Siberian leading corporations also belong to strategic areas, but fewer firms operate in gas and oil industry. As it was showed earlier, levels of leadership stability and sustainability are also lower for Siberian companies.

\section{CONCLUDING REMARKS}

The existence of clearly defined leaders is an important characteristic of any market. Positions of leading corporations, their role and market power are significant elements of the market structure. Our research is based on data of the Russian rating agency. We showed that most national and regional leaders in Russia operate in highly concentrated markets, where competition is rather weak. There are several other ratings of leading companies. It is necessary to mention Global 2000 rating, which is based on Thomson Reuters Fundamentals Worldscope data and is constructed with the help of FactSet Research system ${ }^{10}$. The rating takes into account the same indicators: turnover, gross profit and capitalization, and uses only data concerning companies traded on the stock market. 26 Russian corporations were included in the ranking of 2000 world biggest firms in 2011, while in 2012 the number increased to 28. All these corporations were included in the analysis presented in the paper also because the current research is based on similar criteria.

Most large corporations operate in strategic areas of the economy. They are present in highly concentrated markets, characterized by specific types of competition. Companies' attitude to competition (real and potential) is understood as a very important determinant of their performance, which has significant impact on the decision making and strategic choices. Though most Russian markets do not demonstrate perfect competition, for Russian researchers these questions are extremely important.

According to the High School of Economics (HSE), most Russian enterprises experience competition and take it into account in their decision making ${ }^{11}$. Only small fraction of companies included into the sample (10-20\%) do not experience any competition at all. Main competitors are other Russian companies, foreign companies which sell their products in Russian markets and foreign companies with production plants located in Russia. It was demonstrated that if a company competes with any foreign entity (with and without production in Russia), it attempts to restructure, to introduce new products, to improve technologies and to develop marketing schemes. Competition with domestic rivals motivates cor-

${ }^{10} \mathrm{http}: / / w w w . f o r b e s . c o m / g l o b a l 2000 /$.

${ }^{11}$ Enterprises and Markets in 2005-2009: Results of Survey of Manufacturing Industries (2010), Materials of XI April International Academic Conference on Economic and Social Development, Moscow, p. 150. 
porations to passive restructuring, to abandon unprofitable products and layoff staff. Companies operating in competitive markets usually have great expectations concerning institutional environment.

Each corporation tends to obtain dominant market position and to improve its competitive advantages. This could be achieved by getting high positions in the lists of leaders, developing stable and sustainable leadership.

Search of the ways of effective resistance to main competitors is traditionally considered to be the most important goal of any company. Competitive pressure may be greatly reduced by joining companies in an integrative processes, which is observed in many markets. There are several interesting papers devoted to this issue ${ }^{12}$. An observed formation of various business groups is one of the results of these processes.

Researchers from the HSE showed that business groups in Russia operate as holdings, based on common stock ownership, as corporations with one decision making and controlling centre, as an official financial industrial groups, and as strategic alliances arranged for certain large scale projects. This tendency is typical for many other countries, too.

According to CEFIR data, at the beginning of the $21^{\text {st }}$ century, the largest business groups in the world employed $42 \%$ of all labour resources and controlled $39 \%$ of sales ${ }^{13}$. In highly profitable industries, this share is even higher. $85 \%$ of all shares circulating in the stock market deal with companies which are members of 8 main business groups. Joint research of the World Bank and High School of Economics revealed, that $32 \%$ of all companies (among 1000 respondents) are members of business groups. Integration changes physical firms' boundaries. This may be explained partly by an undeveloped institutional environment. Another important factor influencing integration is globalization, creating serious motivations to increase effectiveness, and create new possibilities. However, it is rather difficult to identify all consequences of globalization for large Russian corporations ${ }^{14}$. Some of them could be negative.

Another important reason for entering new markets is the economy of scale. Thus, large corporations could be more successful in international markets than their smaller competitors ${ }^{15}$.

\footnotetext{
${ }^{12}$ Avdasheva S., Golikova V., Golgopyatova T., Yakovlev A. (2005), Large new Companies ("business groups") in Russian Transition Economy: Problem State in Economic Literature, HSE WP1/2005/09; Avdasheva S. (2006), Business groups in Russian corporate sector: current understanding and new data, Materials of the VII International conference "Economy Modernization and State"; Pappe Ya (2005), Russian Large Business: Subjects Change in 2000-2005, Presentation in CEFIR.

${ }^{13}$ Russian Corporation: Internal Organization, External Influence, Perspectives of Development (2009), Moscow.

${ }^{14}$ Avdasheva S. (2006), op. cit.

${ }^{15}$ Golikova V., Gonchar K., Kuznetsov B. (2012), Influence of Globalization on the Performance of Russian Industrial Enterprise, Materials of XII April International Academic Conference on Economic and Social Development, vol. 4, Moscow, p. 21-30.
} 
Finally, it is necessary to mention several issues concerning the perspectives of corporations' future development. Two key factors substantially influencing the development of Russian corporations could be defined here. They are: increasing role of the state (both in formal and informal ways) and increasing share of stock market in the financing of projects ${ }^{16}$. These tendencies may be expected to advance further in the short term period: rather strict state regulation in strategic industries, certain limits to the involvement of foreign companies in these industries, simultaneous attraction of multinational corporations and long-term foreign investors to non-strategic areas, and the enhancement of integration. In the long term, an increase in the general level of competition, as well as more visible presence of long term strategic investors in Russian markets, development of Russian corporations and their transformation into multinational companies as well as increasing the share and the role of external sources of finance are expected in Russia.

\section{REFERENCES}

Avdasheva S. (2006), Business groups in Russian corporate sector: current understanding and new data, Materials of the VII International conference "Economy Modernization and State", http://conf.hse.ru/2006/prog/20060406 avdasheva. Accessed 20.06.2012.

Avdasheva S., Golikova V., Dolgopyatova T., Yakovlev A. (2005), Large new Companies ("business groups") in Russian Transition Economy: Problem State in Economic Literature, HSE WP1/2005/09, p. 52.

Canhg Yu. (2012), Strategy, Structure and Channels of Industrial Service Leaders, "International Journal Services Technology and Management", vol. 17.

Cheung M.S., Myers M., Mentzer J.T. (2010), Does Relationship Learning Lead to Relationship Value?: A Cross-national Supply Chain Investigation, "Journal of Operations Management", no. 28(6), p. 472-487.

Collins N.R., Preston L.E. (1961), The Size Structure of the Largest industrial Firms, "American Economic Review", vol. 51, p. 986-1011.

Enterprises and Markets in 2005-2009: Results of Survey of Manufacturing Industries (2010), HSE Publishing House, Moscow, p. 150.

Essays of Russian Industry Modernization: Firms Behavior (2014), HSE Publishing House, Moscow, p. 399.

Golikova V., Gonchar K., Kuznetsov B. (2012), Influence of Globalization on the Performance of Russian Industrial Enterprise, Materials of XII April International Academic Conference on Economic and Social Development, vol. 4, Moscow, p. 21-30.

Паппэ Я.Ш. (2009), Российский крупный бизнес: первые 15 лет, Экономические хроники 1993-2008 гг. — М. : Изд. дом ГУ ВШЭ, 423 с.

Perloff J.M., Carlton D. (2004), Modern Industrial Organization, Addison Wesley, p. 392.

Russian Corporation: Internal Organization, External Influence, Perspectives of Development (2009), Moscow, p. 542.

${ }^{16}$ Russian Corporation: Internal Organization, External Influence, Perspectives of Development (2009), Moscow, p. 542. 
Scherer M., Ross D. (1991), Industrial Market Structure and Economic Performance, Houghton Miffin Company, Boston, p. 714.

Toporowski J. (2010), The Transnational Company after Globalization Futures, vol. 42, issue 9, p. $920-925$.

Yang C., Shy J. (2009), Cross-national and Cross-industrial Comparison of two Strategy Approaches for Global Industrial Evolution, "Technological Forecasting and Social Change", vol. 76, issue 1, p. 2-25.

Юсупова А.Т. (2009), Структурные характеристики российских отраслевых рынков, “Регион: экономика и социология", no. 4, p. 175-194.

Ziólkowska M. (2014), Relational Resources Management as Source of Company's Innovativeness and Competitive Advantage, "Journal of Economics, Business and Management", vol. 2, no. 3, p. 202-208.

http://www.raexpert.ru/ratings. Accessed 20.06.2012.

http://www.forbes.com/global2000/. Accessed 10.09.2013. 